\title{
TANGGUNG GUGAT DIREKSI BUMD ATAS KEPUTUSAN YANG MERUGIKAN KEUANGAN BUMD
}

\author{
Roni Fahmi \\ Magister Sains Hukum dan Pembangunan Sekolah Pascasarjana UNAIR \\ Jln. Airlangga No.4-6 Surabaya
}

\begin{abstract}
BUMD is a business entity that all or most of its capital is owned by the region, and was established with the aim of providing benefits for the development of the regional economy in general, organizing public benefits in the form of providing quality goods and / or services for the fulfillment of the livelihood of the community according to conditions, characteristics, and the potential of the area concerned, based on good corporate governance. Management / management of BUMD can not be separated from the role of directors, because directors are BUMD organs responsible for the management of BUMD for the interests and purposes of BUMD, and represent BUMD both inside and outside the court. The problems in this study are about how the scope of accountability of BUMD directors in corporate activities and how to form the accountability of BUMD directors for decisions that are detrimental to BUMD finance. This research is expected to be able to know, describe and analyze the relationship between the scope of accountability with corporate activities and the relationship between the form of accountability with decisions that cause losses.
\end{abstract}

Keywords: BUMD, Directors, Lawsuit

\begin{abstract}
Abstrak
BUMD merupakan badan usaha yang seluruh atau sebagian besar modalnya dimiliki oleh daerah, dan didirikan dengan tujuan untuk memberikan manfaat bagi perkembangan perekonomian daerah pada umumnya, menyelenggarakan kemanfaatan umum berupa penyediaan barang dan/atau jasa yang bermutu bagi pemenuhan hajat hidup masyarakat sesuai kondisi, karakteristik, dan potensi daerah yang bersangkutan, berdasarkan tata kelola perusahaan yang baik. Pengelolaan/pengurusan BUMD tidak bisa dilepaskan dari peranan direksi, karena direksi adalah organ BUMD yang bertanggung jawab atas pengurusan BUMD untuk kepentingan dan tujuan BUMD, serta mewakili BUMD baik di dalam maupun di luar pengadilan. Adapun permasalahan dalam penelitian ini mengenai Bagaimana ruang lingkup tanggung gugat direksi BUMD dalam kegiatan korporasi dan bagaimana Bentuk tanggung gugat direksi BUMD atas keputusan yang merugikan keuangan BUMD. Penelitian ini diharapkan dapat mengetahui, mendeskripsikan dan menganalisis hubungan antara ruang lingkup tanggung gugat dengan kegiatan korporasi dan hubungan antara Bentuk tanggung gugat dengan keputusan yang menimbulkan kerugian.
\end{abstract}

Kata Kunci: BUMD, Direksi, Tanggung Gugat

\section{A. Pendahuluan}

Indonesia menganut konsep negara hukum baru yang lebih dinamis yakni yang dikenal dengan istilah welfare state (negara kesejahteraan) atau negara hukum materiil. Konsep welfare state didalam pemerintah itu diserahi bestuurzorg yaitu penyelenggaraan kesejahteraan umum. Berkaitan dengan konsep negara kesejahteraan yang merupakan revisi dari konsep negara pasif, Asshiddiqie sebagaimana dikutip oleh W Riawan Tjandra menguraikan bahwa dalam konsep negara kesejahteraan ini, negara dituntut untuk memperluas tanggung jawabnya kepada masalah-masalah sosial ekonomi yang dihadapi rakyat banyak. ${ }^{1}$

BUMD merupakan badan usaha yang seluruh atau sebagian besar modalnya dimiliki oleh daerah, dan didirikan dengan tujuan untuk memberikan manfaat bagi perkembangan 
perekonomian daerah pada umumnya, menyelenggarakan kemanfaatan umum berupa penyediaan barang dan/atau jasa yang bermutu bagi pemenuhan hajat hidup masyarakat sesuai kondisi, karakteristik, dan potensi daerah yang bersangkutan, berdasarkan tata kelola perusahaan yang baik. ${ }^{2}$ Penerapan tata kelola perusahaan yang baik tersebut antara lain bertujuan untuk mendorong pengelolaan BUMD secara profesional, efisien, dan efektif, serta memberdayakan fungsi dan meningkatkan kemandirian organ BUMD dan mendorong agar organ BUMD dalam membuat keputusan dan menjalankan tindakan dilandasi nilai moral yang tinggi dan kepatuhan terhadap peraturan perundang-undangan, serta kesadaran tanggung jawab sosial BUMD terhadap pemangku kepentingan maupun kelestarian lingkungan di sekitar BUMD. ${ }^{3}$

Tata kelola perusahaan yang baik tersebut ditetapkan oleh Direksi. ${ }^{4}$ Direksi sebagai salah satu organ BUMD, adalah pihak yang melakukan dan bertanggung jawab atas pengurusan BUMD untuk kepentingan dan tujuan BUMD, serta mewakili BUMD baik di dalam maupun di luar pengadilan sesuai dengan ketentuan anggaran dasar. ${ }^{5}$ Pengangkatan Direksi BUMD didahului dengan proses pemilihan Direksi yang dilakukan melalui seleksi. ${ }^{6}$

Pengelolaan/pengurusan BUMD tidak bisa dilepaskan dari peranan direksi, karena direksi adalah organ BUMD yang bertanggung jawab atas pengurusan BUMD untuk kepentingan dan tujuan BUMD, serta mewakili BUMD baik di dalam maupun di luar pengadilan. Kegigihan direksi dalam memimpin BUMD dengan mengedepankan prinsip-prinsip profesionalitas, profitabilitas, efisiensi, dan inovasi akan memberikan dampak positif bagi BUMD itu sendiri dalam menjalankan fungsi sebagai penyelenggara layanan publik dan agen pembangunan.

Seseorang dapat diangkat sebagai anggota Direksi, yang bersangkutan harus memenuhi syarat sebagai berikut: sehat jasmani dan rohani, memiliki keahlian, integritas, kepemimpinan, pengalaman, jujur, perilaku yang baik, dan dedikasi yang tinggi untuk memajukan dan mengembangkan perusahaan, memahami penyelenggaraan pemerintahan Daerah, memahami manajemen perusahaan, memiliki pengetahuan yang memadai di bidang usaha perusahaan, berijazah paling rendah Strata 1 (S-1), pengalaman kerja minimal 5 (lima) tahun di bidang manajerial perusahaan berbadan hukum dan pernah memimpin tim, berusia paling rendah 35 (tiga puluh lima) tahun dan paling tinggi 55 (lima puluh lima) tahun pada saat mendaftar pertama kali, tidak pernah menjadi anggota Direksi, Dewan Pengawas, atau Komisaris yang dinyatakan bersalah menyebabkan badan usaha yang dipimpin dinyatakan pailit, tidak pernah dihukum karena melakukan tindak pidana yang merugikan keuangan negara atau keuangan daerah, tidak sedang menjalani sanksi pidana dan tidak sedang menjadi pengurus partai politik, calon kepala daerah atau calon wakil kepala daerah, dan/atau calon anggota legislatif. 


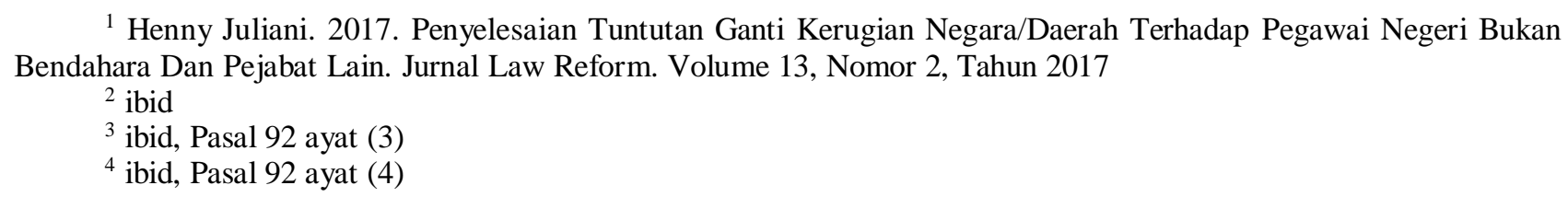

${ }^{1}$ Henny Juliani. 2017. Penyelesaian Tuntutan Ganti Kerugian Negara/Daerah Terhadap Pegawai Negeri Bukan Bendahara Dan Pejabat Lain. Jurnal Law Reform. Volume 13, Nomor 2, Tahun 2017

2 ibid

3 ibid, Pasal 92 ayat (3)

${ }^{4}$ ibid, Pasal 92 ayat (4)

Kasus yang dialami oleh direksi dalam kaitannya dengan masalah penggunaan dana dalam perusahaan. Penyelewangan terjadi yang dilakukan oleh Direksi erat kaitanya dengan tidak bertanggung jawabnya dalam kebijakan mengelola keuangan BUMD. Keuangan BUMD sama hanya dengan keuangan yang berasal dari Anggaran Daerah. Sedangkan BUMN sama hanya dengan keuangan yang berasal dari Keuangan Negara.

Adapun permasalahan dalam penelitian ini mengenai Bagaimana ruang lingkup tanggung gugat direksi BUMD dalam kegiatan korporasi dan bagaimana bentuk tanggung gugat direksi BUMD atas keputusan yang merugikan keuangan BUMD. Penelitian ini diharapkan dapat mengetahui, mendeskripsikan dan menganalisis hubungan antara ruang lingkup tanggunggugat dengan kegiatan korporasi dan hubungan antara Bentuk tanggung gugat dengan keputusan yang menimbulkan kerugian.

Pada akhirnya, pengelolaan pertanggung jawaban keuangan dan pengembangan BUMD hendaknya berada dibawah koordinasi Pemerintah, misalnya Menteri Dalam Negeri atau BPKP yang mengacu kepada UU mengenai Perseroan terbatas yang berbasis pada hukum bisnis (perdata). Berkaitan dengan pentingnya peranan Direksi dalam memimpin BUMD serta tanggung jawab dan resiko yang diembannya dalam mengelola kekayaan daerah. Maka penelitian ini akan membahas mengenai "Tanggung gugat direksi BUMD atas keputusan yang merugikan keuangan BUMD."

\section{B. Method}

Penelitian ini termasuk dalam jenis penelitian deskriptif kualitatif. Dimana peneliti bertindak sebagai instrumen atau kunci utama. Penelitian kualitatif adalah penelitian yang bermaksud untuk memahami fenomena tentang apa yang dialami untuk subyek penelitian, misalnya perilaku, persepsi, motivasi, tindakan-tindakan dan lain-lain. Secara hilostik dan dengan cara deskripsi dalam bentuk kata-kata dan bahasa, pada suatu kontek yang alamiah dan dengan memanfaatkan berbagai metode ilmiah. ${ }^{7}$

\footnotetext{
5 ibid, Pasal 1 angka 18 dan Pasal 55 ayat (1)

${ }^{6}$ ibid, Pasal 58
} 


\section{Analysis And Discussion}

\section{Tanggung Gugat Direksi BUMD dalam Kegiatan Korporasi}

\subsection{Pengertian Tanggung Gugat}

Tanggung gugat seringkali dipadankan dengan istilah yang berbahas Inggris yaitu accountable atau accountability. Dalam hal ini menurut Black's Law Dictionary accountable diartikan sebagai responsive. Sedangkan menurut Contemporary English-Indonesia Dictionary, accountable diartikan sebagai bertanggung jawab. Sedangkan apabila kita definisikan dalam Kamus Besar Bahasa Indonesia Tanggung jawab memiliki arti keadaan wajib menanggung segala sesuatunya sehingga kalau terjadi apa-apa boleh dituntut, dipersilahkan, diperkenankan dan lain sebagainya. Apabila kita coba sandingkan dengan pengertian tanggung jawab serta mencari apa beda dari keduanya.

Pembedaan istilah tanggung jawab dengan tanggung gugat yang mulanya dikenal dalam dunia akademik hukum dan literatur-literatur hokum itu kini telah masuk dalam materi muatan undangundang. Pengertian terkait tanggung gugat salah satunya ada di Undang-Undang Nomor 30 Tahun 2014 tentang Administrasi Pemerintahan (UUAP). Dari keseluruhan isi UUAP ada terminologi tentang tanggung jawab dan tanggung gugat yang terletak pada Pasal 1 angka 23. Di tengah kegamangan terkait konsepsi tanggung gugat ini kita dapat menelaah pendapat Peter Mahmud Marzuki. Beliau mengatakan, bahwa pengertian tanggung jawab dalam arti liability diartikan sebagai tanggung gugat yang merupakan terjemahan dari liability/aanspralijkheid, bentuk spesifik dari tanggung jawab. Menurutnya, pengertian tanggung gugat merujuk kepada posisi seseorang atau badan hukum yang dipandang harus membayar suatu bentuk kompensasi atau ganti rugi setelah adanya peristiwa hukum atau tindakan hukum. Seseorang misalnya harus membayar ganti kerugian kepada orang atau badan hukum lain karena telah melakukan perbuatan melanggar hukum (onrechtmatige daad) sehingga menimbulkan kerugian bagi orang atau badan hukum lain tersebut. Istilah tanggung gugat berada dalam ruang lingkup hukum privat ${ }^{8}$

Pendapat Peter Mahmud Marzuki ini tidak jauh berbeda dengan pendapat ahli hukum perdata di awal abad ke-20 yaitu J.H. Niewenhuis, bahwa tanggung gugat merupakan kewajiban untuk menanggung ganti kerugian sebagai akibat pelanggaran norma.

\subsection{Kewenangan Direksi BUMD}


Disamping Badan Usaha Milik Negara (BUMN), dikenal juga Badan Usaha Milik Daerah (BUMD), yang menurut Undang-undang Nomor 5 Tahun 1962 dikenal dengan nama Perusahaan Daerah. Perusahaan Daerah didirikan berdasarkan peraturan daerah, dan merupakan badan hukum, serta kedudukannya diperoleh dengan berlakunya peraturan daerah tersebut. Badan usaha milik daerah (BUMD) adalah suatu badan yang dikelola oleh daerah untuk menggali potensi daerah, yang bertujuan untuk menambah pendapatan asli daerah yang berguna untuk pembangunan daerah tersebut.

Perusahaan daerah adalah suatu produksi yang bersifat memberi jasa, menyelenggaraan kemanfaatan umum dan memupuk pendapatan. Perusahaan Daerah bergerak dalam lapangan yang sesuai dengan urusan rumah tangganya menurut peraturan perundangan tentang pemerintahan daerah.Undang- undang Nomor 32 tentang Pemerintah Daerah Pasal 177 menyebutkan bahwa Pemerintah Daerah dapat memiliki BUMD yang pembentukan, penggabungan, pelepasan kepemilikan, dan/atau pembubarannya ditetapkan dengan Perda yang berpedoman pada peraturan perundang-undangan.

Pemerintah pemegang hak atas segala kekayaan dan usaha Pemerintah berkedudukan sebagai pemegang saham dalam pemodalan perusahaan.Pemerintah memiliki wewenang dan kekuasaan dalam menetapkan kebijakan perusahaan. Pengawasan dilakukan alat pelengkap negara yang berwenang melayani kepentingan umum selain mencari keuntungan sebagai stabilisator perekonomian dalam rangka mensejahterakan rakyatsebagai sumber pemasukan Negara seluruh atau sebagian besar modalnya milik Negara.Modalnya dapat berupa saham atau obligasi.Bagi perusahaan yang go publik dapat menghimpun dana dari pihak lain, baik berupa bank maupun nonbank. Direksi bertanggung jawab penuh atas perusahaandan mewakili perusahaan di pengadilan.

BUMD memiliki ciri-ciri sebagai berikut :

1. Pemerintah memegang hak atas segala kekayaan dan usaha.

2. Pemerintah berkedudukan sebagai pemegang saham dalam permodalan perusahaan.

3. Pemerintah memiliki wewenang dan kekuasaan dalam menetapkankebijakan perusahaan.

4. Pengawasan dilakukan alat pelengkap negara yang berwenang.

5. Melayani kepentingan masyarakat umum, selain mencari keuntungan.

6. Sebagai stasbilisator perekonomian dalam rangka mewujudkan kesejahteraan rakyat.

7. Sebagai sumber pemasukan negara dan daerah (pendapatan asli daerah). 
8. Seluruh atau sebagian besar modalnya milik pemerintah daerah, dan merupakan kekayaan yang dipisahkan.

9. Modalnya dapat berupa saham atau obligasi bagi perusahaan yang go public.

10. Dapat menghimpun dana dari pihak lain, baik berupa bank maupun nonbank.

11. Direksi bertanggung jawab penuh atas BUMD, dan mewakili BUMD di pengadilan

8 Peter Mahmud Marzuki, Penelitian Hukum, Pengantar Ilmu Hukum, Kencana Prenda Media, Jakarta, 2008, h. 258

Dalam Pasal 1 ayat (4) UUPT direksi adalah salah satu organ perseroan yang bertanggung jawab penuh atas pengurusan perseroan untuk kepentingan dan tujuan perseroan serta mewakili perseroan baik ke dalam maupun di luar pengadilan sesuai dengan ketentuan dalam anggaran dasar perseroan tersebut. Selain itu dalam Pasal 79 ayat (1) dan Pasal 82 dikatakan bahwa "Kepengurusan perseroan dilakukan oleh direksi, dan Direksi bertanggung jawab penuh atas pengurusan perseroan untuk kepentingan dan tujuan perseroan serta mewakili perseroan baik di dalam maupun di luar pengadilana“. Kepengurusan Direksi tidak terbatas pada memimpin dan melakukan kegiatan rutin sehari-hari saja tapi juga wajib mengambil inisiatif dan merancang strategi demi kelangsungan perusahaan dimasa yang akan datang sehingga dapat dicapai maksud dan tujuan perusahaan tersebut.

Rapat Umum Pemegang Sahan (RUPS) adalah forum bagi pemegang saham memperoleh keterangan yang berkaitan dengan perseroan dari direksi dan/atau dewan komisaris, sepanjang berhubungan dengan mata acara rapat dan tidak bertentangan dengan kepentingan perseroan. Direksi merupakan penerima kuasa dari perseroan sesuai dengan kepentingannya untuk mencapai tujuan perseroan sebagaimana telah digariskan dalam ADRT PT, sehingga tidak diperkenankan melakukan sesuatu yang tidak atau bukan menjadi tugasnya. ${ }^{10}$ Komisaris mempunyai tugas utama mengawasi secara umum dan/atau khusus dan memberikan nasehat kepada direksi sesuai Pasal 1 angka 6 dan Pasal 108 ayat (1) UU PT. ${ }^{11}$ Organ perseroan mempunyai kewajiban mewakili perseroan untuk melakukan hubungan hukum dengan pihak ketiga dan untuk mewakili perseroan di dalam pengadilan baik sebagai pengggugat maupun sebagai tergugat. Organ-organ tersebut bertanggungjawab hanya sebatas kewenangannya.

Setiap tugas dan tanggung jawab direksi dalam menjalankan perseroan harus tunduk kepada ketentuan atau peraturan yang mengatur mengenai perseroan sesuai dengan maksud dan tujuan didirikannya perseroan tersebut. ${ }^{13}$ Direksi dalam menjalankan pengurusan perseroan hanya untuk kepentingan perseroan dan sesuai dengan maksud dan tujuan perseroan sebagaimana yang diatur dalam Pasal 92 UU PT. ${ }^{14}$ Pada Pasal 2 UU PTditegaskan bahwa kegiatan perseroan harus sesuai dengan 
maksud dan tujuannya serta tidak bertentangan dengan peraturan perundang-undangan, ketertiban umum, dan atau kesusilaan. Selanjutnya, pada Pasal 18 UU PT ditentukan bahwa maksud dan tujuan tersebut harus dicantumkan dalam ADRT PT sesuai dengan ketentuan

9 Jono, Hukum Kepailitan, Cetakan Ketiga, Edisi Kesatu, Jakarta: Sinar Grafika, 2008, h.55.

${ }^{10}$ Achmad Yani, Seri Hukum Bisnis Perseroan Terbatas, Jakarta: Rajawali Pers, 1999,h.97.

${ }^{11}$ Jono, Hukum Kepailitan, Op. Cit, h. 67.

undang-undang. Penjelasan pada Pasal 18 UU PT disebutkan bahwa maksud dan tujuan tersebut merupakan usaha pokok perseroan, sedangkan kegiatan usaha merupakan kegiatan yang dijalankan oleh perseroan dalam rangka mencapai maksud dan tujuannya yang harus dirinci secara jelas dalam anggaran dasar, dan tidak boleh bertentangan dengannya. Perseroan tidak diperkenankan melakukan kegiatan yang tidak sejalan dengan maksud dan tujuan perseroan.

Pada dasarnya ruang lingkup wewenang direksi yang berhubungan dengan tugas-tugas pengurusan perseroan itu sangat luas. Oleh karena itu, untuk menghindari penyalahgunaan kekuasaan sebagai akibat dari adanya akumulasi dan sentralisasi wewenang direksi, maka perlu adanya pembatasan wewenang direksi. Pembatasan wewenang direksi tersebut hanya dapat dibenarkan sepanjang hal itu tidak meniadakan kemandirian direksi dalam melaksanakan tugas pengurusan. Sebab, pada prinsipnya tugas pengurusan perseroan itu merupakan wewenang otonom direksi, yang terpisah dari segala intervensi komisaris dan pemegang saham. Kemandirian direksi dalam mengurus dan mewakili perseroan, menurut Simanjuntak (1995:32-33), dibatasi oleh undang-undang, anggaran dasar, kepentingan dan tujuan perseroan, asas kewajiban dan kepantasan yang dapat diukur menurut kepentingan umum dan ukuran kesusilaan. Namun, secara umum wewenang direksi dalam menjalankan tugas pengurusan perseroan itu dibatas oleh:

1. Peraturan perundang-undangan, khususnya UUPT;

2. Pembatasan-pembatasan yang tercantum dalam anggaran dasar; dan

3. Maksud dan tujuan serta kegiatan usaha perseroan.

Secara singkat pembatasan wewenang direksi tersebut dapat diuraikan sebagai berikut:

Bahwa meskipun pada dasarnya direksi suatu PT mempunyai kebebasan untuk melakukan suatu tindakan-tindakan pengurusan perseroan dalam arti luas, namun terhadap perbuatanperbuatan tertentu undang-undang membatasi atau memberikan perkecualiannya. Pembatasan ini misalnya menyangkut perbuatan kepemilikan (daden van eigendom) atau perbuatan penguasaan (daden van beschikking). Terhadap perbuatan-perbuatan yang demikian itu, direksi tidak bebas memutuskan sendiri, melainkan terlebih dahulu diwajibkan memperoleh persetujuan dari RUPS atau komisaris. Hal 
ini sesuai dengan Pasal 88 ayat (1) UUPT, yang menentukan bahwa direksi wajib meminta persetujuan RUPS untuk mengalihkan atau menjadikan jaminan utang seluruh atau sebagian besar kekayaan perseroan. Kewajiban minta persetujuan RUPS untuk dapat melakukan perbuatan-perbuatan tersebut dalam Pasal 88 ayat (1) UUPT, menurut Rudhi Prasetya (1996:215-216), merupakan norma baru yang biasanya dalam anggaran dasar cukup dilakukan dengan persetujuan komisaris. Di samping itu, ketentuan tersebut sifatnya memaksa (dwingenrecht), dalam arti kekuasaan RUPS yang demikian itu tidak boleh dihilangkan dalam anggaran dasar dan diganti menjadi kekuasaan komisaris.

\subsection{Tanggung Gugat Direksi BUMD Atas Kewenangan Y ang Dimilikinya}

Badan Usaha Milik Daerah (BUMD) merupakan badan usaha yang dikelola, dibina dan diawasi oleh pemerintah daerah. Sebagian besar bahkan secara keseluruhan modalnya berasal dari negara, yang diambil dari pendapatan masing-masing daerah. Jadi dalam hal ini dapat dikatakan bahwa BUMN sebagai cabang dari BUMN, dimana peranannya sangat penting dalam mengoperasikan dan mengembangkan bidang ekonomi daerah dan nasional.

Dalam PT terdapat 3 (tiga) organ, yakni RUPS, Direksi dm Komisaris. Direksi merupakan satusatunya organ dalarn perseroan yang melaksanakan fungsi pengurusan perseroan. Ada 2 (dua) fungsi utama dari direksi suatu perseroan, yaitu fungsi manajemen, dalam arti direksi melakukan tugas memimpin perusahaan dan fungsi representasi, dalam arti direksi mewakili perusahaan di dalam dan di luar pengadilan. ${ }^{12}$

Direksi yang memperoleh hak dan dibebani oleh kewajiban untuk memutuskan apa yang penting untuk perseroan dan bagaimana melaksanakannya berdasarkan pertimbangan praktis, putusannya bila dilakukan dengan itikad baik dan tujuan yang benar, tidak terbuka bagi pengadilan untuk ditinjau kembali. Keputusan yang diambil melalui dari kegiatan yang dilakukan merupakan salah satu jalan yang keluar dari pikirannya sendiri, apa yang terbaik buat perusahaan, dan mampu dipertanggungjawabkan didepan pengadilan.

Tindakan direksi tidak hanya berdasarakan Peraturan Pemerintah Nomor 54 tahun 2017 tentang Badan Usaha Milik Daerah dan Undang- Undang Nomor 40 Tahun 2007 tentang Perseroan Terbatas ataupu anggaran dasar dari perusahaan, tetapi Direksi juga melakukan tindakan atas dasar ketentuan mengenai fiduciary duty dan business judgment rule.

Direksi dapat memberikan pertimbangan terhadap rapat yang dilakukan oleh pemegang saham pada RUPS maupun rapat RPM pemilik modal yaitu rapat yang dilakukan oleh pemrtintahan daerah. Pengurusan dan perwakilan oleh direksi harus dijalankan sesuai prinsip fiduciary duty. 
Fiduciary duty. A duty to act for someone else's benefit, while subordinating one's personal interests to that of the other person. It is

the highest standard of duty implied by law (e.g. trustee, guardian). ${ }^{13}$

Dalam melaksanakan tugas dan wewenangnya, Direksi harus bertolak dari landasan bahwa tugas dan kedudukan yang diperolehnya berdasarkan dua prinsip dasar, yaitu pertama kepercayaan yang diberikan perseroan kepadanya (fiduciary duty), dan kedua prinsip yang merujuk pada kemampuan serta kehati-hatian tindakan direksi (duty of skill and care).

\footnotetext{
${ }^{12}$ Munir Fuady, Perseroan Terbatas Paradigma Baru, PT. Citra Aditya Bakti, Bandung, 2003, h. 34.

${ }^{13}$ Henry Campbell Black, Op.Cit., h.625
}

Kedua prinsip ini, di samping "statutory duties ", menuntut Direksi untuk bertindak dengan itikad baik, berhati-hati, semata-mata untuk kepentingan dan tujuan perseroan. Pelanggaran terhadap kedua prinsip ini membawa konsekuensi yang berat bagi Direksi, seperti terlihat antara lain dalam Pasal 85 dan Pasal 90 Undang- undang Nomor 1 Tahun 1995 tentang Perseroan Terbatas (UUPT), karena ia dapat dimintai pertanggungjawaban secara pribadi.

Tata kelola dan tata tanggung jawab BUMN/BUMD memiliki kapasitas hukum perdata dimana ketentuan yang mengaturnya adalah peraturan perundang-undangan yang bersifat perdata. Negara dalam kedudukannya pada BUMN/BUMD adalah sebagai subyek hukum perdata, yang tindakan hukumnya semula dalam bentuk tugas dan kewenangan (taak en bevoegdheid) telah berubah menjadi hak dan kewajiban (bekwaamheid) sebagai akibat sebuah transaksi horisontal yang tunduk sepenuhnya pada rezim hukum perdata.

Dengan demikian setiap kewenangan yang dimiliki oleh Direksi Perusahaan umum daerah atau Perusahaan perseroan daerah bersumber dari Undang-Undang maupun Anggaran Dasar, sehingga menimbulkan tanggungjawab. Direksi yang sering kali dalam pelaksanaan tugasnya mengeluarkan keputusan-keputusan yang melahirkan atau tertuju atas perbuatan hukum perdata, seperti halnya melakukan Direksi yang bertindak atas nama Perusahaan melakukan Kerja Sama dengan pihak lain untuk mengembangkan pengelolaan. Keputusan yang sebenarnya bersifat administratif dalam konteks yang mengakibatkan pertanggungjawaban harta kekayaan badan hukum sebagai kedudukan badan hukum perdata.

Kedudukan Direksi dalam pengelolaan kepengurusan BUMD dianggap sebagai pejabat pelaksanaan pemerintahan, sehingga dalam pengelolaannya menggunakan sebagian besar modalnya dari keuangan Negara. Berdasarkan Penjelasan Pasal 2 angka 7 Undang-Undang Nomor 28 Tahun 1999 tentang Penyelenggara Negara yang Bersih dan Bebas dari Korupsi, Kolusi, dan Nepotisme, pada 
angka 1 ditegaskan bahwa Direksi, Komisaris, dan pejabat struktural lainnya pada BUMN dan BUMD merupakan penyelenggara negara. Hal ini karena mereka termasuk ke dalam kelompok pejabat yang mempunyai fungsi strategis dalam kaitannya dengan penyelenggaraan negara sesuai dengan ketentuan peraturan perundangundangan yang berlaku.

Pejabat-pejabat BUMD tersebut bertanggungjawab untuk membawa BUMD sebagai agent of development dengan menggunakan paradigma business judgement rules dan prinsip good corporate governance. Pertanggungjawaban Direksi tersebut dapat dilihat dari adanya kesesuaian dalam pengelolaan perusahaan terhadap peraturan perundang-undangan dan prinsip-prinsip korporasi yang sehat. Berdasarkan hal tersebut, maka apabila Direksi dalam melakukan pengurusan BUMD menimbulkan akibat kerugian keuangan BUMD dikarenakan perbuatan melawan hukum baik sengaja maupun lalai, dapat diintepretasikan merugikan keuangan negara sepanjang memenuhi rumusan ketentuan peraturan perundang-undangan yang mengaturnya.

Kedudukan Direksi dalam kepengurusan dan pengelolaan perusahaan umum daerah dan perusahaan perseroan daerah bersifat mandiri, tidak tunduk pada RUPS dan KPM maupun pada Komisaris. Atau dalam hal ini disebut sebagai Business Judgement Rule, namun ada pembatasan ialah oleh:

1. Peraturan Perundang-undangan;

2. Maksud dan tujuan dalam anggaran dasar;

3. Pembatasan-pembatasan dalam anggaran dasar

Dalam perwakilan dan tugas kewenangannya terdapat pada pasal 98 Undang- Undang Perseroan Terbatas berbunyi;

1. Direksi mewakili Perseroan baik di dalam maupun di luar pengadilan. (2) Dalam hal anggota Direksi terdiri lebih dari 1 (satu) orang, yang berwenang mewakili Perseroan adalah setiap anggota

Direksi, kecuali ditentukan lain dalam anggaran dasar.

2. Kewenangan Direksi untuk mewakili Perseroan sebagaimana dimaksud pada ayat (1) adalah tidak terbatas dan tidak bersyarat, kecuali ditentukan lain dalam undang-undang ini, anggaran dasar, atau keputusan RUPS.

3. Keputusan RUPS sebagaimana dimaksud pada ayat (3) tidak boleh bertentangan dengan ketentuan Undang-Undang ini dan/atau anggaran dasar Perseroan.

Tanggunggugat pada perseroan terbatas menitikberatkan pada tanggungjawab direksi dalam mengurus suatu perseroan. Tanggunggugat yang dilaksanakan menimbulkan konsekuensi atau halhal yan perlu dipikul oleh Direksi. Pada pasal 97 Undang-Undang Perseroan Terbatas menyatakan; 
1. Direksi bertanggung jawab atas pengurusan Perseroan sebagaimana dimaksud dalam Pasal 92 ayat (1).

2. Pengurusan sebagaimana dimaksud pada ayat (1), wajib dilaksanakan setiap anggota Direksi dengan itikad baik dan penuh tanggung jawab.

3. Setiap anggota Direksi bertanggung jawab penuh secara pribadi atas kerugian Perseroan apabila yang bersangkutan bersalah atau lalai menjalankan tugasnya sesuai dengan ketentuan sebagaimana dimaksud pada ayat (2).

4. Dalam hal Direksi terdiri atas 2 (dua) anggota Direksi atau lebih, tanggung jawab sebagaimana dimaksud pada ayat (3) berlaku secara tanggung renteng bagi setiap anggota Direksi.

5. Anggota Direksi tidak dapat dipertanggungjawabkan atas kerugian sebagaimana dimaksud pada ayat (3) apabila dapat membuktikan:

a. kerugian tersebut bukan karena kesalahan atau kelalaiannya;

b. telah melakukan pengurusan dengan itikad baik dan kehati-hatian untuk kepentingan dan sesuai dengan maksud dan tujuan Perseroan;

c. tidak mempunyai benturan kepentingan baik langsung maupun tidak langsung atas tindakan pengurusan yang mengakibatkankerugian; dan

d. telah mengambil tindakan untuk mencegahtimbul atau berlanjutnya kerugian tersebut.

6. Atas nama Perseroan, pemegang saham yang mewakili paling sedikit 1/10 (satu persepuluh) bagian dari jumlah seluruh saham dengan hak suara dapat mengajukan gugatan melalui pengadilan negeri terhadap anggota Direksi yang karena kesalahan atau kelalaiannya menimbulkan kerugian pada Perseroan.

7. Ketentuan sebagaimana dimaksud pada ayat (5) tidak mengurangi hak anggota Direksi lain dan/atau anggota Dewan Komisaris untuk mengajukan gugatan atas nama Perseroan.

Tanggung gugat yang dilakukan secara tanggung renteng bagi setiap anggota Direksi. Tanggung renteng berasal dari kata tanggung berarti memikul, menjamin, menyatakan ketersediaan untuk membayar utang orang lain bila orang tersebut tidak menepati janjinya. Sedangkan kata renteng berarti, rangkaian, untaian. ${ }^{14}$ Tanggung renteng didefinisikan sebagai tanggung jawab bersama diantara anggota dalam satu kelompok atas segala kewajiban terhadap koperasi dengan dasar keterbukaan dan saling mempercayai. ${ }^{15}$ 
Dalam pelaksanaan tanggunggugat ini dilakukan secara permanen, yaitu Karen a dalam pelaksanaannya dilakukan berdasarkan peraturan perundang-undangan, sehingga secara hakikatnya sudah melekat sejak

sesorang diangkat menjadi pejabat Direksi. Nilai yang terkandung dalam sistem tanggung renteng $\operatorname{adalah}^{16}$;

a. Kekeluargaan dan kegotong royongan.

b. Keterbukaan dan keberanian mengemukakan pendapat.

c. Menanamkan disiplin, tanggung jawab dan harga diri serta rasa percaya diri kepada anggota.

d. Secara tidak langsung menciptakan kader pimpinan di kalangan anggota.

Sedangkan dalam pelaksanaan terdapat Pengecualian terhadap tanggung jawab secara renteng oleh anggota direksi terjadi apabila dapat membuktikan:

1. Kerugian tersebut bukan karena kesalahan atau kelalaiannya;

2. Telah melakukan pengurusan dengan itikad baik dan kehati-hatian untuk kepentingan dan sesuai dengan maksud dan tujuan Perseroan;

3. Tidak mempunyai benturan kepentingan baik langsung mapun tidak langsung atas tindakan pengurusan yang mengakibatkan kerugian; dan

\footnotetext{
${ }^{14}$ Pusat Bahasa, Kamus Besar Bahasa Indonesia Online, (http://kbbi.web.id/, 2016), diakses 10 November 2016.

${ }^{15}$ Gatot Supriyanto, Aplikasi Sistem Tanggung Renteng Koperasi Setia Bhakti Wanita Jawa Timur, (Surabaya: Kopwan Setia Bhakti Wanita, 2009), 36.

4. Telah mengambil tindakan untuk mencegah timbul atau berlanjutnya kerugian tersebut.

Mekanisme Tanggung Renteng dilakukan secara 2 macam jenis yaitu, (1) mekanisme Pengambilan Keputusan, pengambilan ini dilakukan dengam melibatkan seluruh anggota Direksi. (2) Mekanisme Kontrol, membuat anggota Direksi wajib malakukan tanggungjawab dan menanggung beaban atas tindakan kepengurusan dan pengelolaan BUMD.
}

\section{Tanggung Gugat Direksi BUMD Atas Keputusan Yang Merugikan BUMD 2.1 Produk Hukum dalam BUMD}

Pembentukan BUMD yang dalam rangka mendorong pembangunan daerah ditetapkan melalui Peraturan Daerah dan mendapatkan modal dasar pembentukan dari kekayaan daerah yang dipisahkan dari Anggaran Pendapatan dan Belanja Daerah (APBD). Peraturan daerah pembentuk BUMD dan Kebijakan yang ada di dalam BUMD dipegang sepenuhnya dipegang Kelapa Daerah yang kedudukan hukum bersangkutan BUMD. Kepala Daerah pemegang kekuasaan dalam pengelolaan 
keuangan daerah dan mewakili Pemerintah Daerah dalam kepemilikan Kekayaan Daerah Yang Dipisahkan.

Adanya kewenangan yang besar dari pemerintahan daerah yang dalam pengelolan BUMD ini dilakukan oleh Kepala Daerah memberikan kewenangan dalam pengambilan keputusan atas pengelolaan BUMD. Kewenangan pengambilan keputusan yang dimiliki tersebut berdasar atas target kinerja BUMD, Klasifikasi hasil pengelolaan Kekayaan daerah yang dipisahkan sesuai jenis bidang usaha BUMD, dan laporan keuangan BUMD.

Pengelolaan BUMD tidak hanya dipegang sepenuhnya oleh Kepala Daerah, Karena jenis BUMD merupakan perusahaan Umum daerah ataupun perusahaan perseroan daerah maka mengenal adanya komisaris, direksidan/atau dewan pengawas dari perusahaan BUMD tersebut. Atau dalam hal ini organ pengelola BUMD, dijelaskan dalam Pasal 29 Peraturan Pemerintah Nomor 54 tahun 2017 tentang Badan Usaha Milik Daerah, menyatakan organ BUMD jenis (1) Perusahaan umum Daerah terdiri atas KPM (perwakilan pemerintahan daerah), Dewan Pengawas dan Direksi. Sedangkan pada (2) perusahaan perseroan daerah terdiri atas RUPS (Rapat Umum Pemegang Saham), Komisaris dan Direksi.

Kemudian dari organ-organ tersebutlah pengelolaan dan kepengurusan BUMD berjalan berdasarkan tujuan kebutuhan daerah dari aspek pelayanan umum dan kebutuhan masyarakat. Dari organ yang ada terdapat tugas dan fungsi masing-masing seperti halnya mengambil keputusan atau kebijakan yang ada di dalam BUMD.

${ }^{16}$ Andriani S. Soemantri, dkk, Bunga Rampai Tanggung Renteng, (Malang: Puskowajanti LIMPAD, 2001), 37.

Produk hukum dalam BUMD dilakukan oleh organ yang menjalankan pengelolaan dan kepengurusan dari BUMD. Produk hukum yang dikeluarkan tersebut berdasar atas kebutuhan dan kepentingan dari perusahaan, seperti halnya yang dikeluarkan lewat Keputusan hasil rapat tahuanan atau harian yang lakukan oleh pengelola perusahaan BUMD tersebut. Keputusan yang diambil oleh organ tersebut sesuai dengan tugas dan fungsi organ masing- masing dan tindakan pengambilan keputusan dilandasi nilai moral yang tinggi dan kepatuhan terhadap peraturan perundang-undangan, serta kesadaran tanggung jawab sosial BUMD terhadap pemangku kepentingan maupun kelestarian lingkungan di sekitar BUMD

Adapun salah satu Keputusan yang menjadi Perbuatan Hukum atas BUMD ialah seperti Keputusan yang berkaitan dengan kegiatan usaha Kerja sama dengan pihak lain, keputusan pengelolaan dana ataupun pengembangan usaha BUMD terhadap usaha masyarakat mikro serta kebutuhan penanaman modal atau investasi dan pelayanan publik. Investasi adalah penanaman modal untuk satu atau lebih aktiva yang dimiliki dan biasanya berjangka waktu lama dengan harapan mendapatkan keuntungan di masamasa yang akan datang. 


\subsection{Hakikat Keputusan Direksi BUMD}

Direksi diberi dua fungsi dalam mengemban tugasnya, yaitu fungsi pengurusan (manajemen) dan fungsi perwakilan (representasi). Fungsi pengurusan seorang direksi dilakukan ketika direksi mengemban tugasnya sebagai seorang yang mengurus perseroan sehari-hari. Fungsi perwakilan adalah tugas direksi mewakili perseroan baik di dalam maupun di luar pengadilan. Begitu besar dan luas keweangan seorang direksi perseroan. Tugas yang diemban oleh direksi ini harus dijaga dan dilaksanakan sebaik- baiknya. Kewenangan yang diperoleh direksi dari para pemegang saham (shareholder) didasarkan atas kepercayaan (fiduciary) untuk mengurus perseroan demi kepentingan perseroan, bukan demi kepentingan pemegang saham atau pihak tertentu. Fidusia (fiduciary) dalam bahasa latin dikenal sebagai fiduciarus yang bermakna kepercayaan. Secara teknis dapat dimaknai sebagai memegan suatu dalam kepercayaan untuk kepentingan orang ${ }^{17}$

Seorang direksi tidak dapat dimintai pertanggungjawaban secara pribadi atas tindakan yang telah dilakukannya dalam kedudukannya sebagai direksi, apabila ia meyakini bahwa tindakan tersebut merupakan tindakan yang terbaik bagi perseroan dan dilakukan secara jujur, beritikad baik, dan tidak bertentangan dengan hukum yang berlaku. Direksi tidak akan dimintai pertanggungjawaban walaupun salah mengambil keputusan (mere errors of judgement) ketika direksi beritikad baik dan penuh kehatihatian dalam menjalankan tugasnya. Hal ini akan membantu direksi karena hakim tidak diperbolehkan melakukan penilaian bisnis yang berbentuk second guess

${ }^{17}$ Ridwan Khairandy, Perseroan Terbatas Doktrin, Peraturan Perundang- undangan dan Yurisprudensi, Edisi Revisi, Total Media, Yogyakarta, 2009, h. 204.

terhadap keputusan bisnis yang diambil oleh direksi sesuai dengan teori keputusan bisnis (business judgement rule). ${ }^{18}$ Setiap keputusan direksi yang diambil dilindungi oleh business judgement rule, namun direksi tetap harus beritikad baik, berhati-hati, dan penuh loyalitas dalam menjalankan kepengurusan perseroan.

\subsection{Bentuk Tanggung Gugat Direksi Atas Keputusan Yang Merugikan}

Hukum merupakan cermin yang memantulkan kepentingan masyarakat. Karena kepentingan masyarakat selalu berubah, maka secara operasional hukum juga dituntut untuk selalu mengubah dirinya. Apabila dilihat secara sosiologis perangkat aturan hukum telah menjelmakan dirinya menjadi responsive law brarti yang termaju dalam fase perkembangan hukum karena hukum berkembang dari represissve law menjadi autonomous law dan kemudian berbentuk responsive law, ${ }^{19}$ bahkan saat ini hukum yang sedang dikembangkan kearah hukum yang progresif atau progresive law. 
Dalam merespons kepentingan masyarakat, hukum tidak selalu menyediakan perangkatnya persis seperti apa yang terjadi dalam masyarakat bahkan lebih dari itu hukum harus juga memberi bentuk kepada masyarakat, yakni menyediakan platform kearah tujuan pembangunan masyarakat itu sendiri. Dalam konteks ini, hukum dikenal dengan istilah "tool of social engineering" ${ }^{20}$. Dalam dunia hukum bisnis, tensi terhadap perubahan hukum cukup tinggi, karena bisnis sendiri berkembang begitu cepat sedangkan hukum bisnis (perangkat peraturannya) seringkali tertinggal ${ }^{21}$

Secara konseptual, BUMD didirikan atas dasar dualisme fungsi dan peranan, yang keduanya sangat sulit, jika tidak dapat dikatakan mustahil, untuk dipadukan. Seperti BUMN, ia punya tugas dalam mengembangkan perekonomian daerah melalui peranannya sebagai institusi public service. Namun pada saat yang sama, BUMD juga

diharapkan mampu menghasilkan laba dari usahanya selaku pelayan masyarakat. Secara implisit, BUMD dijadikan sumber dana APBD. Dalam ketentuan, BUMD diwajibkan menyetorkan bagian labanya sebagai dana pembangunan daerah sebesar 55\% dari laba bersih tahunan. Dalam tataran operasionalnya, peran dan fungsi ini dilaksanakan secara distortif. Fungsi service lama-kelamaan bergeser sebagai fungsi ekploitatif.

18 Munir Fuady, Doktrin-doktrin Modern Dalam Corporate Law, Op.cit.,hlm. 48.

19 Bernad L Tanya, Simanjuntak, Yoan N, Hage, Markus Y, 2006, Teori Hukum, Strategi Tertib Manusia Lintas Ruang dan Generasi, Surabaya, CV Kita, h.70

${ }^{20}$ Munir Fuady, 1994, "Potret Hukum Bisnis Kita Dewasa Ini”, Surat kabar Bisnis Indonesia, 15 Oktober 1993, dalam : Hukum Bisnis Dalam Teori dan Praktek Bagian Kesatu, Bandung, Citra Aditya Bakti, h. 1.

21 Ibid.

Keberadaan PT BUMD setelah berubah bentuk dari PD hanya akan eksis dan berkelanjutan tidak hanya didukung oleh regulasi yang jelas namun yang terpenting adalah penempatan orangorang yang tepat (dalam hal ini adalah tentang SDM) pada organ perusahaan, khususnya pada direksi dan komisaris.

Istilah GCG semakin populer dan mendapatkan tempat di bidang hukumkorporasi karena terwujud dalam dua keyakinan, yaitu : Pertama, GCG merupakan salah satu kunci sukses perusahaan untuk tumbuh dan menguntungkan dalam jangka panjang, sekaligus memenangkan persaingan bisnis global, terutama bagi perusahaan yang telah mampu berkembang sekaligus menjadi terbuka. Kedua, 
krisis ekonomi dunia, di kawasan Asia dan Amerika Latin yang diyakini muncul karena kegagalan penerapan GCG. ${ }^{22}$

Penerapan prinsip-prinsip GCG dapat menciptakan suasana kondusif bagi kelancaran pengelolaan bisnis perusahaan, termasuk meningkatkan daya saing. GCG menjadi salah satu daya tarik investor dan para kreditor untuk mau meminjamkan dananya kepada perusahaan.

Good corporate governance memiliki nilai-nilai positif untuk menjaga konsistensi serta profesionalisme perusahaan dalam melakukan berbagai macam tindakan menuju kearah kinerja yang lebih baik. Hal ini didasarkan bahwa dalam GCG terdapat empat prinsip, yaitu pinsip kewajaran, keterbukaan informasi, dapat dipertanggungjawabkan dan pertanggungjawaban. ${ }^{23}$

Sebagian besar perusahaan yang tidak stabil, disebabkan oleh sikap dan cara pengelolaan yang tidak menerapkan nilainilai GCG secara tepat sehingga untuk menjaga agar perusahaan tetap stabil, maka semua kekuatan sumber daya perusahaan secara keseluruhan dan utuh harus mampu menjaga efektivitas, efisien dan produktivitas dari asset-liability-equity perusahaan, termasuk cash flow dan profit perusahaan dalam keseimbangan yang tepat dengan cara-cara pengelolaan yang patuh pada penerapan prinsip-prinsip GCG.

22 Dyah Permata BudiAsri, "Pelaksanaan Good Corporate Governance Dalam UU Nomor 40 Tahun 2007 Tentang PT', tersedia di website http://janabadra.cic.id/ujb/00-2411-7401-pdf), diakses pada tanggal 14 Januari 2020.

23 Ibid.

korporasi yang terkait dengan etika dan moral serta nilai-nilai penerapan prinsip-prinsip GCG.

Peranan GCG selain dapat membuat perusahaan menjadi kuat dankokoh juga dapat melakukan semua kewajibankewajibannya kepada para pemegang saham maupun stake holders seperti gaji karyawan, biaya-biaya opersional rutin, biaya bunga pinjaman, baik biaya- biaya tetap maupun biaya- biaya tidak tetap lainnya, dengan melalui sistem dan kultur atau budaya

\section{Conclusion}

Adapun kesimpulan yang dapat saya jelaskan pada penelitian ini berdasarkan kajian dan analisis di atas adalah sebagai berikut : 
12. Tata kelola dan tata tanggung jawab BUMN/BUMD memiliki kapasitas hukum perdata dimana ketentuan yang mengaturnya adalah peraturan perundang-undangan yang bersifat perdata. Negara dalam kedudukannya

pada BUMN/BUMD adalah sebagai subyek hukum perdata, yang tindakan hukumnya semula dalam bentuk tugas dan kewenangan (taak en bevoegdheid) telah berubah menjadi hak dan kewajiban (bekwaamheid) sebagai akibat sebuah transaksi horisontal yang tunduk sepenuhnya pada rezim hukum perdata. Dengan demikian setiap kewenangan yang dimiliki oleh Direksi Perusahaan umum daerah atau Perusahaan perseroan daerah bersumber dari Undang-Undang maupun Anggaran Dasar, sehingga menimbulkan tanggungjawab. Direksi yang sering kali dalam pelaksanaan tugasnya mengeluarkan keputusan-keputusan yang melahirkan atau tertuju atas perbuatan hukum perdata, seperti halnya melakukan Direksi yang bertindak atas nama Perusahaan melakukan Kerja Sama dengan pihak lain untuk mengembangkan pengelolaan. Keputusan yang sebenarnya bersifat administratif dalam konteks yang mengakibatkan pertanggungjawaban harta kekayaan badan hukum sebagai kedudukan badan hukum perdata.

13.Mengingat Perusahaan Daerah berada pada dua ranah hukum yaitu hukum

public dan hukum privat, maka kewenangan dan tanggung jawab berkaitan dengan perusahaan daerah meliputi: Ranah hukum publik pemerintah daerah memiliki kewenangan dan tanggung jawab terhadap segala kegiatan, penguasaan dan pengurusan perusahaan daerah, sepanjang berkaitan dengan pembentukan, kepemilikan modal, dan pengawasan perusahaan daerah. Sedangkan Ranah hukum privat direksi selaku organ perusahaan memiliki kewenangan dan tanggung jawab penuh dalam menjalankan kegiatan operasional perusahaan daerah dalam hal berinteraksi dengan pihak ketiga seperti mengadakan perjanjian, mewakili perusahaan baik di dalam maupun di luar pengadilan.

\section{Bibliography}

Achmad Yani, Seri Hukum Bisnis Perseroan Terbatas, Jakarta: Rajawali Pers, 1999,h.97.

Andriani S. Soemantri, dkk, Bunga Rampai Tanggung Renteng, (Malang: Puskowajanti LIMPAD, 2001), 37

Bernad L Tanya, Simanjuntak, Yoan N, Hage, Markus Y, 2006, Teori Hukum, Strategi Tertib Manusia Lintas Ruang dan Generasi, Surabaya, CV Kita, h. 70 
Dyah Permata BudiAsri, "Pelaksanaan Good Corporate Governance Dalam UU Nomor 40 Tahun 2007 Tentang PT', tersedia di website http://janabadra.cic.id/ujb/00-2411-7401-pdf), diakses pada tanggal 14 Januari 2020.

Gatot Supriyanto, Aplikasi Sistem Tanggung Renteng Koperasi Setia Bhakti Wanita Jawa Timur, (Surabaya: Kopwan Setia Bhakti Wanita, 2009), 36.

Henny Juliani. 2017. Penyelesaian Tuntutan Ganti Kerugian Negara/Daerah Terhadap Pegawai Negeri Bukan Bendahara Dan Pejabat Lain. Jurnal Law Reform. Volume 13, Nomor 2, Tahun 2017 Henry Campbell Black, Op.Cit., h.625

Jono, Hukum Kepailitan, Cetakan Ketiga, Edisi Kesatu, Jakarta: Sinar Grafika, 2008, h.55. \& 67

Lexy J Moleong, Metode Penelitian Kualitatif, Remaja Rosdakarya, Bandung, 2005, h. 6.

Munir Fuady, Doktrin-doktrin Modern Dalam Corporate Law, Op.cit.,hlm. 48.

Munir Fuady, Perseroan Terbatas Paradigma Baru, PT. Citra Aditya Bakti, Bandung, 2003, h. 34.

Munir Fuady, 1994, "Potret Hukum Bisnis Kita Dewasa Ini”, Surat kabar Bisnis Indonesia, 15 Oktober 1993, dalam : Hukum Bisnis Dalam Teori dan Praktek Bagian Kesatu, Bandung, Citra Aditya Bakti, h. 1.

Peter Mahmud Marzuki, Penelitian Hukum, Pengantar Ilmu Hukum, Kencana Prenda Media, Jakarta, 2008, h. 258

Pusat Bahasa, Kamus Besar Bahasa Indonesia Online, (http://kbbi.web.id/, 2016), diakses 10 November 2016.

Ridwan Khairandy, Perseroan Terbatas Doktrin, Peraturan Perundang-undangan dan Yurisprudensi, Edisi Revisi, Total Media, Yogyakarta, 2009, h. 204. 